\title{
TRIAP1 Gene
}

National Cancer Institute

\section{Source}

National Cancer Institute. TRIAP1 Gene. NCI Thesaurus. Code C106453.

This gene is involved in the inhibition of apoptosis. 